CATHARSIS 9 (1) 2020

Halaman: 58-64

p-ISSN 2252-6900 I e-ISSN 2502-4531

UNNES

Catharsis: Journal of Arts Education

http://journal.unnes.ac.id/sju/index.php/chatarsis

\title{
Jonggan Dayak Kanayatn Dance: Study of Educational Values in The Learning Process in Elementary Schools
}

\author{
Mukhlisin $^{凶}$, Hartono Hartono, Restu Lanjari \\ Email: mukhlisin12@yahoo.com \\ Universitas Negeri Semarang, Indonesia
}

Received 26 December 2019, Accepted 20 February 2020, Published 31 May 2020

\begin{abstract}
The learning process is inseparable from the educational values that occurs during the learning and teaching activities taking place, and also in the learning process of Jonggan Dayak Kanayatn Dance. This study examined the educational value in the learning process of Jonggan Dayak Kanayatn Dance in elementary schools. This research used qualitative method and educational approach. Data collection used observation, interview and document study technique. Data analysis procedures used data reduction, data presentation and data verification. Analysis of the educational value in the learning process of Jonggan Dayak Kanayatn Dance used Rosyadi and Hasbullah Analysis. The validity of the data in this study used triangulation of data sources. The results of the study were: 1). Religious Value; 2). Discipline Value; 3). Responsibility Value; 4). Independence Value; 5). Tolerance Value and Hard Work Value. Specifically, the findings in the Jonggan Dayak Kanayatn Dance learning process, there was an educational value that is reflected in the Jonggan Dayak Kanayatn Dance learning process in Elementary Schools. The benefits of the results of this study can be used as a reference in dance learning in particular and in learning other arts in general.
\end{abstract}

Keywords: Jonggan Dance, Dayak, Educational Value

DOI : https://doi.org/10.15294/catharsis.v8i4.37181 


\section{INTRODUCTION}

Learning is the process of interaction of students with educators and learning resources in a learning environment. Learning is an aid given by educators to enable the process of acquisition of knowledge and knowledge, mastery of skills and character and form attitudes and beliefs in students (Rachmawati and Daryanto, 2015: 3839).

Learning is a process carried out by educators to teach students in certain learning environments and finally changes in behavior. Because learning is a process, naturally in a process there are interrelated components. The main components in learning include learning objectives, educators, students, curriculum, learning strategies, learning media, and learning evaluation (Racmawati and Daryanto, 2015: 3839).

The learning process is inseparable from the educational value that occurs during the process of learning and learning takes place, where a learning has an important meaning in achieving the objectives to be achieved that can shape humans into fully human beings. Coaching activities are a learning process carried out by two actors namely the teacher and the students. the behavior of teachers and students is doing a learning process (Rusman, 2014: 141).

The educational value is absolutely necessary to support national character building (Ministry of National Education, 2012: 2) especially in primary education children who have experienced initial physical and psychological growth, so that it is very appropriate to instill character in it. Subjects that can give, instill, and create good character to students one of which is subjects related to art. Through art, children can obtain aesthetic experiences related to visual elements, sound and motion (Salam in Kusumastuti, 2010: 4).

Jonggan dance is one of the arts in West Kalimantan Province, folk dance type and functions as an entertainment dance. Tari Jonggan tells the joy and happiness of the Dayak community in general. Jonggan in Dayak Kanayatn which means Joget, while Bajonggan which means dancing. Jonggan dance is one of the dances that is still preserved by the people of West Kalimantan (Setiawan, 2017: 2).

Jonggan dance is presented in the form of group dance. Jonggan dance is carried out in Elementary School Learning. where Jonggan Dance has been packaged in the form of Learning in Elementary Schools.

This research is based on several previous studies that have been done before relating to the object being studied, namely research Malarsih (2013) The process of learning dance involves preparation, training, and performance. The teacher carries out this stage in order to improve student learning outcomes and time effectiveness. Factors that influence the process of learning dance usually consists of supporting factors and inhibiting factors.

Subsequent research conducted by Malarsih (2013) Learning dance by teachers can be done using an appreciation and creation approach. Rahmani (2010) Learning tambourine dance that examines the form and learning. Research conducted by Nurseto (2015) Learning Dance in Elementary Schools using active and passive appreciation with the stages of description, analysis, interpretation and assessment / evaluation.

Palevi (2013) The study examines the form of a tradition, the educational value, and the folklore function of its traditions. His findings can 
be used to compare similarities and differences in other research positions.

The next previous study conducted by Safitri et al (2016) The learning process in class VIII with Laweut Traditional Dance material based on floor patterns using modeling techniques. With these results it shows that by using the modeling method, students will be more active in the learning process and will get maximum marks during the exam.

This study aims to analyze the educational values that are applied in the learning process of Jonggan dance in elementary schools. It is hoped that this research can enrich or develop science as one of the studies of art and culture, especially relating to culture contained in a dance. This research is also expected to be able to broaden horizons and as a reference for scientific studies relating to Dance Learning in the local area.

\section{METHOD}

This study uses qualitative research methods and education approaches. With a case study research design, which means the findings in this study only apply to the same characteristics and phenomena. The objectives of the study in this study are the educational values that are applied in the learning process of Jonggan Dayak Kanayatn Dance. The location of the study was conducted at Batu Ampar 04 Elementary School. Data collection techniques are done through observation, interviews and document studies. Observations were made to observe the environment of the study site, Batu Ampar 04 Elementary School, the main object is the educational value in the learning process of Jonggan dance. The interview was conducted at the Principal of Batu Ampar 04 Elementary
School, art teacher, dance trainer, to get very accurate information from the relevant informant. The interview was conducted by recording and recording the results of the conversation between researcher and resource person. Study documents are used for data relating to school documents related to research.

The data validity technique in this study uses triangulation techniques, namely source triangulation, meaning that the trust testing process can be carried out by examining data that has been obtained through various sources. Triangulation of sources conducted by researchers is through resource persons related to various information about Jonggan Dance Learning at Batu Ampar 04 Elementary School.

Data analysis techniques through the stages of reduction or sorted out and presented in the form of a special format according to the nature of the data that allows, to then go through the stages of presentation, and verification.

\section{RESULTS AND DISCUSSION}

The learning process is inseparable from the educational value that occurs during the process of learning and learning takes place, where a learning has an important meaning in the direction of the objectives to be achieved that can shape humans into fully human beings. Coaching activities are a learning process carried out by two actors namely the teacher and the students. the behavior of teachers and students is doing a learning process (Rusman, 2014: 141).

The educational value is absolutely necessary to support national character building (Ministry of National Education, 2012: 2) especially in primary education children who have experienced initial physical and psychological growth, so that it is very 
appropriate to instill character in it. Subjects that can give, instill, and create good character to students one of which is subjects related to art. Through art, children can obtain aesthetic experiences related to visual elements, sound and motion (Salam in Kusumastuti, 2010: 4).

In connection with the discussion of educational values that are applied in the learning of Jonggan Dayak Kanayatn Dance at Batu Ampar 04 Elementary School by resting on the field data obtained from the results of observations, it will be elaborated on the educational values in learning Jonggan Dayak Kanayatn Dance at Batu Ampar 04 Elementary School.

\section{Religious Value}

Religion does not only involve the outward aspect of life but also involves the total aspect of the total human self as a whole in its integration of relationships into the impression of God (Rosyadi, 1995: 90). Religious Value is a reflection of the variety of Jongong dance movements. This is reflected in the movement of greetings, where the motion of greetings is one of the movements that illustrates respect for guests or spectators who come. It can be seen that there is a value of religious education in the learning process of Jongong dance, that this dance teaches us to respect each other, because it is a very important thing in life, because it can have a positive impact and can hone the values of other lives.

\section{Discipline Value}

According to Suyadi (2015: 8), argues that discipline is a habit or an action that is very consistent with all forms of regulations or rules that have been in force. proven that learning has been structured with a predetermined schedule. so that in this Jongong dance coaching is established with good cooperation between trainers / teachers and students. Discipline is needed in daily life in order to appreciate the time associated with learning dance Jongong and students also obey about the clothes that have been predetermined that is wearing sports clothing.

\section{Responsibility Value}

Responsibility is a human awareness of behavior or intentional or unintentional actions, responsibility also means to act as an expression of awareness of its obligations. It means to be oriented towards others giving attention to them, the responsibility of emphasizing positive obligations in order to care for one another (Lickona, 2014: 63).

During the learning process of Jonggan Dayak Kanayatn Dance, the trainer gives examples of the movements that have been given in order to remind students and do their movements simultaneously. Analysis of the learning activities of Kangann Jonggan Dance in Batu Ampar 04 Elementary School related to the Value of Responsibility, it appears that students are very active in doing various kinds of Jonggan Dance movements and students can memorize various movements associated with the learning process of Jonggan Dance.

It was also seen that students who participated in the Jongong dance learning process could work together in their dance groups and fulfill their obligations to carry out the process of activities and memorize the various movements of Jonggan Dayak Kanayatn Dance.

\section{Independence Value}

Independent is an attitude and behavior that does not depend on others in completing various tasks or problems (Suyadi, 2015: 8), while 
Nashir (2013: 86) that independent attitude is an extraordinary potential because of someone's independence or a nation can develop its ability to be equal and even superior to others.

Activities related to the learning process of Jonggan Dayak Kanayatn Dance, contain the value of independence education, namely during the activities of students in order to memorize and remember the variety of movements of Jongong dance without being accompanied by a trainer. Each student must have different problems faced, too, meaning that students must be independent in making decisions to be able to solve and resolve the problems they face related to learning Jongayat Dayak Kanayatn Dance.

\section{Social Value}

Rosyadi (1995: 80) states that social behavior in the form of a person's attitude towards events that occur around him that has to do with other people, ways of thinking, and social relations between individuals.

Social Values in the learning process of Jonggan Dance can be seen in the intertwining of communication between one individual and another individual, group one with other groups. In addition to being in charge of remembering the variety of Jongong dance movements that have been given by the trainer, the students also inspect each other. Practicing together together is a very fun social thing done by students at Batu Ampar 04 Elementary School. Clearly reflected the sense of togetherness and communicative and friendship made by students in the learning process of Jonggan Dance. Where this value is really needed when the students go back into the field to become a community, through this activity and good and polite communication it creates a good collaborative atmosphere towards the surrounding community.

\section{Cultural Value}

Rosyadi (1995: 74), states that cultural values are something that is considered good and valuable by a group of people or ethnic groups that are not necessarily seen well by a group of people and other ethnic groups, because the value of buadaya limits and gives characteristics to a society and culture in each region.

Jonggan dance can be used as a cultural medium, efforts so that students recognize cultural values is not enough by reading it alone, but must also be given insights and sufficient knowledge, they may be able to play an active role in physically feeling and empathizing with artistic activities (Hidajat, 2008: 18).

In line with that opinion, Jonggan dance is one of the learning activities carried out at Batu Ampar 04 Elementary School, which has a meaningful representation of activities that contain value in everyday relationships in the community, that this activity reflects on the norms and social relationships where students at teach good behavior through the activities of the arts especially the art of Jonggan Dance.

Related to the learning process of Kangann Jonggan Dayak Dance which is carried out at Batu Ampar 04 Elementary School followed by students is a transmission of cultural values and other educational values. Jonggan dance is an activity that instills life values so that students can later conduct life in a good society.

Based on the description that has been explained that in the learning process of Jonggan Dayak Kanayatn Dance there are educational values, namely religious education values, social education values, moral education values and cultural education values and complemented with character education values that refer to good behavior, meaning that if those values are implemented well it will be able to achieve goals 
in life related to relationships within the community well.

This research can enrich or develop science as one of the studies of art and culture, especially relating to culture contained in a dance. This research is also expected to be able to broaden horizons and as a reference for scientific studies related to the culture in the local area.

The contribution in this research for educational institutions is that it can give learners a new experience and to be able to feel and enjoy the emerging art work so as to provide an appreciation, as well as an in-depth understanding of the art of Jonggan dance taught through the dance learning process at school.

\section{CONCLUSION}

The conclusions in this study are related to the educational values that are applied in the learning process of Jonggan Dance in Batu Ampar 04 Elementary School, Belimbing District, West Kalimantan, which consists of: (1). The value of religious education, reflected in mutual respect and respect for differences. (2). Moral Education Values, consisting of the value of disciplinary education, where the value of this education is reflected in the timeliness for training, the responsibility is reflected in students having a sense of responsibility to remember the variety of dance movements, the value of independent education, reflected in students having to practice on their own without asked by the coach. (3). The value of Social Education is reflected in the occurrence of an interaction and collaboration between individuals and groups in the learning process of Jongong dance. (4). The value of Cultural Education, reflected in the dance learning process that there is cultural transmission at Batu Ampar 04 Elementary
School related to Jonggan Dayak Kanayatn Dance and leads to positive activities undertaken by students.

\section{REFERENCES}

Hasbullah. (2005). Dasar-dasar Ilmu Pendidikan. Jakarta: Raja Grafindo Persada.

Kemendiknas, (2012). Sistem Pendidikan Nasional. Jakarta.

Kusumastuti. (2010). Strategi Pembelajaran. Jakarta

Malarsih, (2013). Pembelajaran Seni Tari di SMP Negeri 1 Batangan Kabupaten Pati. Catharsis, Vol. 2, No 1. Universitas Negeri Semarang http://doi.org./10.15294/jst.v2i1.9619

Malarsih, (2013). Pembelajaran Seni Tari Menggunakan Pendekatan Apresiasi dan Kreasi. Penerapan Teknologi dan Pembelajaran, Vol. 11, No. 2. Universitas Negeri Semarang http//doi.org./10.15294/rekayasa.v11i1.1033 5

Nashir, Haedar. (2013). Pendidikan Karakter berbasis Agama dan Budaya. Yogyakarta: Multi Presindo

Nurseto, G (2015). Pembelajaran Seni Tari: Aktif, Inovatif dan Kreatif. Jurnal Cataharsis, 4(5) Universitas Negeri Semarang

Palevi, Ade Reza. (2013). Bentuk dan Nilai Pendidikan dalam Tradisi Guyuban bagi Kehidupan Masyarakat Desa Pasir Ayah Kebumen. Jurnal Pendidikan, Bahasa, Sastra, dan Budaya Jawa. Vol. 3. No.3. 35-39.

Rachmawati dan Daryanto, (2015). Teori Belajar dan Proses Pembelajaran yang Mendidik. Yogyakarta : Gava Media.

Rahmani, Dwi. (2010). Pembelajaran Tari Rebana Pada Sanggar Tari Kreasi Senja di Kecamatan Selo Kabupaten Boyolali. Jurnal Abdi Seni Vol. 2. No.2.

Rosyadi. (1995). Nilai-nilai Budaya dalam Naskah $K a ' b a$. Jakarta :CV Dewi Sri.

Rusman. (2014). Model-Model Pembelajaran. Jakarta: PT Raja Grafindo Persada.

Safitry Y, (2016) Proses Pembelajaran pada Materi Tari Tradisional Laweut Berdasarkan Pola Lantai dengan Menggunakan Metode Pemodelan di Kelas 
02 SMP Negeri 14 Banda Aceh. Jurnal Ilmiah Mahasiswa, 1(4) : 325-333. Universitas Syiah Kuala Aceh Setiawan (2017). Bentuk Penyajian Tari Jonggan Suku Dayak Kanayatn di Kecamatan Kubu
Kabupaten Kubu Raya. Jurnal Pendidikan dan Pembelajaran Khatulistiwa Vol. 6, No 8 eISSN : 2715-2723

Suyadi. (2015). Strategi Pembelajaran Pendidikan Krakter. Bandung: PT Remaja Rosda 